\title{
Vulnerability Index Analysis of Bepondi Island as a Reference for Small and Outer Islands Management in Indonesian
}

\author{
Puji Rahmadi* \\ Research Center for Oceanography, Indonesian Institute for Science (LIPI), Jl. Pasir Putih 1, Ancol \\ Timur, Jakarta, Indonesia
}

\begin{abstract}
Indonesia is an archipelagic country with many small islands as the outer border of the territory. Special attention and development programs are important due to it relates to the improvement of public welfare and national sovereignty. Therefore, the vulnerability study for small and outer islands is urgently conducted as an initial step for regional development programs. This study aims to analyze the vulnerability level of Bepondi Island, West Papua from various threats either directly from nature by biologically, geologically, climate change effect, or anthropological and social-economic. To determine the small and outer island's vulnerability, composite vulnerability index (CVI) has been applied. Several ecological indexes have been composited were coastal index (CI), Isolation Index (II), Land-used degradation index (LDI), Ecosystem degradation index, and Sea Level Rise Index (SLRI). The results showed that Bepondi Island has CVI calculated for 0.47 , which means the island was exposed to medium-high vulnerability. This was caused by the threat from abrasion, potential landslide, and isolation. On the other hand, this island has a fairly high fishery potential. Therefore, mitigation plans to cope with disasters were urgently needed and communication infrastructures must be promptly built as a countermeasure for the island's isolation problem.
\end{abstract}

\section{Introduction}

Indonesia is an archipelagic country with more than 17.000 islands. The archipelagic layout of the country means that there are many small islands that are situated at the outermost territory or at the edge of the national territory border. The Outermost Small Islands (OSI) were situated far from the capital region and center of development, therefore they are usually faced with limited infrastructure and limited economic development. Based on this condition, special attention for OSI is urgently needed both for improving the welfare of the community and as an effort to uphold the sovereignty of the Nation.

\footnotetext{
${ }^{*}$ Corresponding author: puji.rahmadi@gmail.com
} 
In the preparation for regional development planning, a preliminary study of the condition of islands needs to be conducted. Regarding OSI, the biggest issue is the level of vulnerability and resilience from changes caused by nature, such as climate change, disasters, also changes in the socio-economic condition of the related communities [1]. The assessment of small island vulnerability factors is crucial because it serves as a guide for policymakers and decision-makers to develop and managing those regions. The vulnerability of small islands can be interpreted as a level of the system on an island to bear the burden of change until it cannot maintain its original condition [2]. The vulnerability of small islands usually determined by its physical, environmental, social and economic components of the islands [2]. Therefore, a study of vulnerability assessment of small islands is needed as a basis for making development plannings and to identify possible threats such as; natural threats, biological, geological, and unforeseen hazards due to climate change, as well as the threat of social sectors.

The study of small islands vulnerability index has been applied in many outer islands of Indonesia. One of them is the assessment of vulnerability index for Barang Lompo Island in Makassar [3]. The study showed that the island was in danger by the threat of sea-level rise and it could make the island sink in the next few years. In retrospect of the previous studies, mitigation actions and management directions were needed to be conducted, so that the island can be saved or at least the rate of deterioration can be slowed down. The importance of vulnerability index study for OSI in this paper is expected to have at least the same important value as the results of the previously mentioned study in Barang Lompo. Other studies on small island vulnerability have also been conducted in Seribu Islands [4, 5]. The study reported that the pressure given by high number of population and pollutants runoff from 4 different rivers originating from Jakarta and Banten were greatly affected the environmental degradation of the Seribu Islands. Another study on the vulnerability of small islands has also been carried out by Rosmawati (2018) [6] at Pari Island, Jakarta. This study reported that mass tourism in Pari Island was giving great pressure on ecological degradation [6]. Based on the previous accounts, vulnerability analysis is vital to be an input for policymakers in preparation for adapting action plans in the future.

Presidential Decree 2017 Number 6 stated that Bepondi Island has been recognized as one of the Outermost Small Islands. Bepondi has a relatively high population density with 640 people in an area of $5.4 \mathrm{~km}^{2}$. Before 2014, this island is a favorite place for foreign fishing vessels to transit and resupplying freshwater and logistics. These phenomena were driving social and economic progress on the island. However, along with the regulation from the Indonesian Ministry of Maritime and Fisheries Affairs concerning the Prohibition of Foreign Ships to enter Indonesian territory, foreign fisheries vessel never docked in Bepondi island anymore and it negatively impacted the local economy. On the other hand, history recorded Bepondi Island have exposed by several natural disasters threatening the sustainability of Island. In this case, government intervention is urgently needed as a form of state recognition in the outermost island of Indonesia. Destructive disasters that happened in Bepondi as recorded by the Indonesian government were listed as follows;

1. Meteorological, Climatological, and Geophysical Agency (BMKG) recorded between 1966 and 2017, Bepondi island was struck with destructive earthquakes 22 times [7].

2. BMKG recorded between 1864 to 2017, there were 10 times of instances of tsunami waves that hit Bepondi Island.

3. Based on the "Earthquake Source and Hazard Map Book in 2017" by National Earthquake Study Center, Ministry of Public Works and Public Housing: the north and eastern part of Biak was the area with the most frequently occurring earthquakes with a magnitude of $>5.5$ [8]. While earthquakes with a magnitude of $>7$ occurred in 1996, 1947 and 1941. In 1996 there was a massive earthquake triggering a tsunami with a wave reaching $7 \mathrm{~m}$ of height [9]. Related with the previously mentioned conditions, the study 
of the vulnerability of this Island becomes important and development as a follow up from the result should be prioritized by the government.

\section{Materials and Methods}

This study was conducted during the Expedition of Nusa Manggala (ENM). Data collection on this study was recognized into three different types, which were;

- Direct/in situ measurement, monitoring, satellite image analysis also drone survey were applied to collect information on the physical condition of subjected Island.

- In-depth interviews with semi-structured and open-ended questions were used to explore the social-economic condition of the population inhabit on Island.

- Secondary data were cited and reviewed from several related sources.

- Data analysis were done referring to several published paper.

\subsection{Vulnerability index analysis}

The small and outer island's vulnerability index has been determined based on the concept reported by [1], where vulnerability $(\mathrm{V})$ is a function from exposure $(\mathrm{E})$, sensitivity $(\mathrm{S})$, and adaptive capacity (AC), and was expressed on mathematical function as;

$$
\mathrm{V}=\mathrm{f}(\mathrm{E}, \mathrm{S}, \mathrm{AC})
$$

The equation was then simplified as:

$$
\boldsymbol{V}=\boldsymbol{E}+\boldsymbol{S}-\boldsymbol{A C}
$$

The parameters used to identify exposure were coastline changes, sea-level rise, tidal range fluctuation, history of earthquake and tsunami, and population growth. Sensitivity parameter was indicated from coastal type, land-use, ecosystem degradation, MPA and distances between islands.

\subsection{Composite analysis for vulnerability index at small islands}

To determine the small and outer island's vulnerability, five independent indexes are composited and expressed into Composite vulnerability index (CVI). The independent indexes were:

a. Coastal index (CI),

$$
C I_{i}=\frac{L_{i}}{A_{i}}
$$

Coastal index value could be determined by dividing the island's shore length ( $\mathrm{Li})$ with the island area $(\mathrm{Ai})$.

b. Insularity Index (II), 


$$
I I_{i}=\sum_{j=1}^{3} \sqrt{S_{i j}}
$$

$$
\begin{array}{ll}
\mathrm{II} & =\text { Insularity Index } \\
\mathrm{i} & =\text { Island Name } \\
\mathrm{S}_{\mathrm{ij}} & =\text { distance to mainland } \mathrm{J} \\
1 & =\text { distance from nears small island } \mathrm{J} \\
2 & =\text { distance to other land }-1 \mathrm{j} \text { (small/bigger) } \\
3 & =\text { distance to other land }-2 \mathrm{j} \text { (small/bigger) }
\end{array}
$$

The insularity index represents the remoteness, level of isolation, and how the island's size potentially brings threats to the sustainability of the island.

c. Land-used degradation index (LDI),

$$
L D I=\frac{B L_{i}}{A_{i}} \times 100
$$

Land-used degradation index is an indicator of threat caused by the conversion of lands into buildings, homes, or other structures. This index could be determined by dividing land converted (BLi) with the total area on the same island (Ai).

d. Ecosystem degradation index (EDI),

EDI expressed how the ecosystem condition contributes to the vulnerability of the island. In the small islands, EDI was identified using the condition of Coral Reef, Mangrove and Seagrass ecosystem. In this study, data of Coral Reef was obtained using Underwater Photo Transect (UPT) done by Coral Monitoring Team in ENM. The EDI values for Mangrove and other ecosystem could not be determined since the data series was not available. The data collection was performed by one-time sampling done in ENM. The EDI value for coral could be calculated as follow;

$$
C C D=\frac{D C C_{i}}{C E A_{i}} x 100
$$

Coral Cover Degraded (CCD) is determined by dividing Dead Coral Cover (DCC) with those all Coral Ecosystem Area (CEA).

e. Population Index (PopI).

Population Index describes the growth of citizen population related to island area and land occupation. The higher population growth is, the threats from human activity will be higher to the vulnerability of the island. Population Index is determined as follows:

$$
\text { Popl }=\left(\left(\frac{N A_{i t}}{50}\right) x\left(\frac{\text { Trend }_{i, t-1}}{2}\right)\right)
$$


vulnerability was determined using pairwise comparison matrix [3]. This matrix is able to show the relativity effect from every element to the expected result.

There are several methods for determining the small and outer island's vulnerability index. The methods previously described were selected in order to obtain results that could be compared with similar studies conducted in different places.

\section{Results and Discussion}

The field survey results showed that Bepondi Island has the highest altitude of $165 \mathrm{~m}$ above sea level, and the cross fault of the soil layer has been found in the hilltop of this island. The shore area has a steep slope $\left(>60^{\circ}\right)$ and receives collapsing waves from the ocean. These conditions caused a massive abrasion that significantly changed the coastline. The nearest land from Bepondi is a village that belongs to Supiori District, which can be reached through sea trip for about 6 hours depending on the weather condition. Even though the social level of community was moderate and there were many local economic transactions, the citizens are isolated from the outside world since there was no access to telephone, TV, internet and other communication devices. There was also no regular ferry/vessel transportation service either held by the government, private sector, or individual. Vulnerability indices were calculated as follow:

a. The coastal vulnerability index score calculated was 1.8 and standardized into 0.36 which means low vulnerability [10].

b. Insularity Index (II) score was calculated to be 0.52 which means medium vulnerability. This Island has a distance relatively far from other islands, i.e. 32.6 $\mathrm{km}$ from the nearest mainland and 42.6 to the other small islands inhabited by people. The II suggested that this island was isolated from the outer world by common transportation. This inference was validated by interviews demonstrating that the people need at least 6-7 hours to travel from their Island to the nearest mainland if the weather is good. This meant that they cannot go back and forth in a single day.

c. Land-used Degradation Index (LDI) score was calculated to be 0.14 which means very low vulnerability. This number represents how the natural condition of land converted into buildings and other structures with the consequences of changing ecological function. The number was very low because only minimalist houses, schools, churches, and some public facility have been built on the island. People also tended to stay with their parents even though they had been married. Therefore, the development of land conversion occurred slowly and resulted in low vulnerability.

d. Ecosystem Degradation Index (EDI) score was calculated to be 0.5 which means medium vulnerable. This means that the degradation was progressively and relatively fast to give a threat to the sustainability of the island. Steep slopes in the coastal and steep hillside in the land induced high abrasion and erosion, causing ecosystems especially coral reef hard to survive. Steep hillside also caused soils to be easily released into the ocean.

e. Population Index (PopI) was calculated to be 0.024 which means very low vulnerable. This index shows how population growth will bring a threat to the island. Since the population growth was very low in $2018(2 \%)$ and population density was recorded in the number of $112 / \mathrm{km}^{2}$ (BPS, 2018, Profile of Bepondi Villagevul, 2017) therefore this sector does not pose a threat to the sustainability of the island. 
Based on the data collected, Composite Index analysis has resulted in a value of 0.47 , which means the island was exposed to medium vulnerability by interactions of the whole sector threatening Island.

Table 1. Composite Index analysis scores

\begin{tabular}{lccccc}
\hline Index & CVI & II & LDI & EDI & Pop.I \\
\hline Result & 0.36 & 0.52 & 0.14 & 0.5 & 0.03 \\
Composite Index & 0.47 & & & & \\
\hline
\end{tabular}

Composite Index score between 0 - 0.2 is categorized as Non-Vulnerable, $0.2-0.4$ is Low Vulnerable, $0.4-0.6$ is Medium Vulnerable, $0.6-0.8$ is Highly Vulnerable and $0.8-1.0$ indicates extremely Vulnerable.

Based on the Composite Index score, Bepondi Island is identified as having medium vulnerability while accounting threats of abrasion, potential landslides, communication isolation, also transportation isolation. Contrasted to the threats, this island has a fairly high fishery potential and a high density of population. It is therefore imperative to formulate a mitigation plan to cope with disasters. Infrastructures for communication services must also be built as soon as possible to solve the isolation issues. Referring to Indonesian Law No. 24 of 2007, disaster management is the obligation of the State. Therefore, it is necessary to carry out mitigation efforts to reduce the impact and forming resilient communities on Bepondi Island. With isolation problems and the lack of communication and transportation infrastructures, the people of Bepondi Island were considered very vulnerable to disasters because the emergency response would be difficult to carry out. However, the people of Bepondi Island have local wisdom in dealing with disasters related to tsunami, which became the basis of community resilience in facing disasters. Finally, we hope the results of this study can be used as consideration for stakeholders and policymakers to make the development and disaster mitigation programs for small and outer islands in Indonesia.

In conclusion, Bepondi Island has fairly high fisheries potential and a relatively big population but it was threatened with medium level vulnerability. A mitigation plan to cope with disasters is urgently needed, and the development of communication and transportation infrastructures must be shortly built to solve the island's isolation.

This paper was written using data from the Expedition of Nusa Manggala (ENM). ENM is an expedition program funded by Research Center for Oceanography (RCO - LIPI) by COREMAP scheme. The author would like to thank RCO for granting a chance to join the expedition so this paper can be finished as it is expected. Furthermore, the author wished this result can be used by stakeholder as a reference for better management and assigning development programs

\section{References}

1. B. L. Turner, R. E. Kasperson, P. A. Matsone, J. J. McCarthy, R. W. Corell, L. Christensen, N. Eckley, J. X. Kasperson, A. Luers, M. L. Martello, C. Polsky, A. Pulsipher, and A. A. Schiller. Framework for vulnerability analysis in sustainability science. Proc. Natl. Acad. Sci. U.S.A. 100:8074-8079 (2003)

2. C. Polsky, R. Neff, B. Yarnal. Building comparable global change vulnerability assessment: The vulnerability scoping diagram. Global Environmental Change (17) 472 - 485. (2007)

3. A. Tahir, M. Boer, S. B. Susilo, and I. Jaya. Indeks Kerentanan Pulau - Pulau Kecil: Kasus Pulau Barrang Lompo-Makasar. Indonesian Journal of Marine Science. December 2009 Vol. 14 (4): 183-188 (2009) 
4. A. R. Farhan, and S. Lim. Resilience Assessment of on Coastal Changes and Urban Settlement: a case study in Seribu Islands Indonesia. Ocean and Coastal Management 54: 391-400. (2011)

5. A. R. Farhan, and S. Lim. Vulnerability Assessment of ecological Conditions in Seribu Islands Indonesia. Ocean and Coastal Management 65: 1-14 (2012)

6. A. Rosmawati. Penilaian Indeks Kerentanan Pulau-Pulau Kecil Studi Kasus: Pulau Pari, Kepulauan Seribu, DKI Jakarta. Thesis for Master degree. Institut Pertanian Bogor. Bogor. (2018)

7. M. Sadly, R. Triyono, T. Prasetyo, S. D. Anugrah, Budiarta, U. Setiyono, I. Gunawan, Priyobudi, Yatimantoro, Hidayanti, S. Anggraini, R. H. Rahayu, D. S. Yogaswara, A. M. Julius, M. Apriyani, M. Harvan, and G. Simangunsong. Katalog Tsunami Indonesia per wilayah 416-2017, Kedeputian Bidang Geofisika, Badan Meteorologi, Klimatologi dan Geofisika. Jakarta. (2018)

8. M. Irsyam, S. Widiyantoro, D. H. Natawidjaja, I. Meilano, A. Rudyanto, S. Hidayati, W. Triyoso, N. R. Hanifa, D. Djarwadi, L. Faizal, and Sunarjito. Peta Sumber dan bahaya Gempa Indonesia Tahun 2017. Pusat Penelitian dan Pengembangan Perumahan dan Pemukiman, Badan Penelitian dan Pengembangan, Kementerian Pekerjaan Umum dan Perumahan Rakyat. Bandung. (2017)

9. C. Henry, and S. Das. The M W 8.2, 17 February 1996 Biak, Indonesia, Earthquake: Rupture History, Aftershocks, and Fault Plane Properties. Journal of Geophysical Research 107, no. B11, ESE-11, pp.16 (2002)

10. Cambridge University. https://climate-adapt.eea.europa.eu/metadata/tools/coastalvulnerability-index-2013-cvi (2005) 